\title{
WHAT LIES BENEATH: \\ L1 MORPHOSYNTAX SEEPING IN THROUGH YOUNG LEARNERS' EFL
}

\begin{abstract}
Recent findings regarding L1 use among students learning English as a Foreign Language (EFL) have called into question the notion of a negative correlation between proficiency and lexical crosslinguistic influence (CLI). However, interaction-based studies often focus on CLI via explicit L1 use exclusively. While this study also analyses explicit L1 use, it primarily taps into the underlying impact of L1 morphosyntax shaping part of the students' oral production in L2, a fact which has already been pointed out in the literature, yet needs looking into in further detail.
\end{abstract}

Participants were 20 children aged 8 L1 Spanish beginner learners of English at a CLIL programme. They took on the narrator role in a communicative task which they carried out firstly with i) an expert speaker of English and, subsequently with ii) a matched-level peer.

The results boast an extremely low rate of explicit L1 use, yet reveal the existence of more pervasive CLI in the form of structural transfer, particularly so when children interacted with their peers. This fact might hint at a trade-off strategy for their low mastery of the target language.

\section{Introduction}

Most research on oral interaction in Second Language Acquisition (SLA) spawned from the interactionist framework (Long, 1996), and has defined the features and learning opportunities of learners' negotiations considering a myriad of variables, such as age, level, context and task-type, to name but some.

Research analysing the benefits of interaction for SLA initially focussed on adult learners (e.g. Gass \& Varonis, 1985a; Pica \& Doughty, 1985b; P. A. Porter, 1986; Yule \& Macdonald, 1990). Subsequent studies by Alison Mackey and Rhonda Oliver (Mackey \& Oliver, 2002; Mackey, Oliver, \& Leeman, 2003; Oliver, 1995a, 1995b, 1998, 2000, 2002; Oliver \& Mackey, 2003; Philp, Oliver, \& Mackey, 2008) included children learning English as a Second Language (ESL). However, data from children learning English as a foreign language (EFL) remained non-existent until more recent research (Azkarai \& Imaz Agirre, 2015; M.P. García Mayo \& Lázaro-Ibarrola, 2015a; Lázaro-Ibarrola \& Azpilicueta-Martínez, 2015; Lázaro-Ibarrola \& Hidalgo, 2017; Philp \& Tognini, 2009; Tognini, 2008; Tognini \& Oliver, 2012).

Regarding EFL (and CLIL) interaction-based research, some of the commonly addressed features are negotiation for meaning strategies (including, in turn, conversational adjustments and repetitions) and explicit L1 use. The latter element is undergoing a shift in the way it is perceived as of late, given the studies showing the benefits of a balanced explicit L1 use in interaction (M. P. García Mayo \& Hidalgo, 2017; Lázaro \& Garcia Mayo, 2012; Macaro, 2005; Neokleous, 2017). A recent study by Lázaro-Ibarrola and Hidalgo (2017) warned about the occurrence of abundant L1 structural tranfer in their data (young L1 Spanish EFL learners engaged in oral interaction, 
a similar setting to the present study) and advocated the inclusion of this phenomenon as an object of study in subsequent interaction-based studies (e.g., M. P. García Mayo \& Hidalgo, 2017; Lázaro-Ibarrola \& Hidalgo, 2017).

This study attempts to shed light on the oral CLI of 20 young L1 Spanish learners of English enrolled in a CLIL programme while performing a picture-based task which embeds a spot-the-difference ${ }^{1}$ activity within a story. Specifically, we will analyse all instances of explicit L1 use and structural transfer in their interactions.

\section{Literature review}

\subsection{L1 use: proficiency and age}

Young learners (hereinafter 'YLs') have been reported to need to resort to the L1 while producing in the TL at early stages of its acquisition (Agustín-Llach, 2009; Celaya \& Torras, 2001; Gabrys-Barker, 2006; Gost \& Celaya, 2005). This has been attributed to lexical lacunae in their L2 coupled with the need to communicate in the target language (TL), and is widely regarded as a common compensatory communication strategy (Celaya, 1992; Ecke, 2001; James, 2013).

However, explicit L1 use among students still appears to be frowned upon by certain educators on the grounds that learners will fail to perform the tasks at hand in the TL (Storch \& Aldosari, 2010; Tognini \& Oliver, 2012), in spite of the substantiated benefits of a balanced explicit L1 use reported in the literature (Antón \& DiCamilla, 1998; DiCamilla \& Antón, 2012; M. P. García Mayo and Hidalgo (2017); Lázaro \& Garcia Mayo, 2012; e.g., Macaro, 2005; Neokleous, 2017; Storch \& Aldosari, 2010).

Different scholars have suggested that proficiency in the TL and explicit L1 use show a negative correlation (Agustín-Llach, 2009; Herwig, 2001; Jarvis \& Pavlenko, 2008; Navés, Miralpeix, \& Celaya, 2005; Odlin \& Jarvis, 2004; Serra, 2007; Storch \& Aldosari, 2010). In other words, explicit L1 use appears to be inversely proportional to the mastery of the TL. However, a number of studies have cast doubt on such clear-cut interrelationship (e.g., Sánchez, 2003; Sanz, 2000).

Recently, a growing body of interaction-based research has compared, among other variables, explicit L1 use in children learning English as a Foreign Language (EFL) and learners in Content and Language Integrated Learning (CLIL) programmes (e.g., Azkarai \& García Mayo, 2017; Azkarai \& Imaz Agirre, 2015; M. P. García Mayo \& Hidalgo, 2017; M.P. García Mayo \& Lázaro-Ibarrola, 2015b), with mixed results hinting at additional factors playing a central role in the students' degree of reliance on their L1.

On the one hand, recent studies have reported higher levels of L1 terms in mainstream (hereafter MS) EFL learners than their age-matched, more proficient CLIL counterparts (Azkarai \& Imaz Agirre, 2015; M.P. García Mayo \& Imaz Agirre, 2017; M.P. García Mayo \& Lázaro-Ibarrola, 2015b), supporting previous claims by Möhle (1989), Poulisse (1990), and Poulisse and Bongaerts (1990).

\footnotetext{
${ }^{1}$ See 4.2. 'The Task”.
} 
By contrast, the latest research by Pladevall-Ballester and Vraciu (2017) revealed similar rates of explicit L1 use in both instructional settings (CLIL and MS EFL), while a study by AUTHOR (2015) reported a minimal percentage of explicit L1 use $(0.52 \%)$ in MS EFL learners with a considerably low command of the TL.

Interestingly, recent research has also revealed opposing results regarding age and explicit L1 use, with studies reporting greater explicit L1 use by the older students (e.g., M. P. García Mayo \& Hidalgo, 2017; M.P. García Mayo \& Lázaro-Ibarrola, 2015b), while Azkarai and Imaz-Agirre (2015) (MS EFL) and Pladevall-Ballester and Vraciu (2017) hint at the opposite, concurring with previous work by Pinter (2006).

García-Mayo and Hidalgo (2017) point at "learner motivation, task complexity, task repetition and instructional setting” (M. P. García Mayo \& Hidalgo, 2017, p. 133) as key elements impinging on the amount of L1 in the learners' output. Likewise, and, in spite of the low L1 rates in some of the research above, the same authors (M. P. García Mayo \& Hidalgo, 2017; Lázaro-Ibarrola \& Hidalgo, 2017) have brought into light the existence of abundant L1 'structural transfer' (M. P. García Mayo \& Hidalgo, 2017, p. 141 ) in their data, understood as ungrammatical instances of the TL.

Non-explicit CLI with Spanish learners of English has already been object of study. For example, Celaya (1992) analysed the way the L1 (Spanish and/or Catalan) affected the TL of secondary-school students via structural L2 choice (Celaya, 1992). Among other things, she found out how the Spanish and Catalan tense systems may lead to an overgeneralisation in the use of the simple present in English when referring to present time, as a consequence of the "different distributions of forms and meanings in English and Spanish and Catalan tense-systems" (Celaya, 1992, p. 29).

The present work, by contrast, addresses the way the L1 might lead the student's production to produce ungrammatical forms in the TL, which would otherwise constitute grammatically valid utterances in the L1 if translated word for word.

\subsection{L1 use: the interlocutor and task factors}

The interlocutor factor is one of the aspects subject to affect the amount and type of interaction in an SL or FL at different levels. Circumstances such as age, gender, personality or status have long been investigated in the literature (Berry, 1997; Buckingham, 1997; D. Porter, 1991; D. Porter \& Shen, 1991, to name but some), and are ultimately thought to exert some influence as regards language choice (e.g., Allwright, 1996; Bell, 1984).

Regarding low-level children, research by Lyster and Izquierdo calls to question the suitability of content-based tasks with young children whose command of the target language might be too low (R. Lyster, 2001; R. Lyster \& Izquierdo, 2009). An empirical study by Lyster (2001) with young students (ages 8-10) learning French in an immersion context, claims that, in communicatively oriented classrooms " young L2 learners may not readily notice target-non target mismatches in the interactional input" (R. Lyster, 2001, p. 268). Lyster's study, therefore, seems to indicate that children are perhaps able to interact but may not do so in a way that promotes accuracy. 
A study by Broner (2001) investigated, among other elements, the interlocutor and task factor in relation to the amount of TL use with 10-year-old students in a Spanish immersion context in the US. She concluded that interlocutor, task-content and "being on/off task" all played central roles in the amount of TL and L1 produced by the students. By being 'on-task' Broner referred to language use "in which the children are speaking about and are engaged in the assigned task", whereas 'off-task' language included language tokens "in which the children are not carrying out the assigned task" (Broner, 2001, p. 126) She pointed at the adult expert speaker of TL Spanish holding the teacher role in her study as directly boosting the students' output in that language, yet also explained how activities which forced the students to focus on the TL in peer-peer interaction, such as creative writing, led to a proportionally higher TL output (though not entirely L1-free) than other types of activities in non-language-related contents (e.g., maths and science). In addition, Broner's study revealed a significantly higher number of L1 items during off-task communication, as opposed to García-Mayo and Hidalgo (2017), whose results displayed no instances of explicit L1 use in off-task interaction whatsoever.

A recent study on peer-peer interaction by Lázaro-Ibarrola and Hidalgo (2017) delved into the benefits and limitations of conversational interactions among 11-year old learners of English in a CLIL context which was very similar to the one in the present study. While not central to their study, these authors report abundant instances of CLI via structural transfer, and explain that i) such instances never triggered recasts or explicit corrections from their interlocutor, i.e., they were likely to be understood by their counterparts, and ii) such structural transfer appeared to be 'mirrored' in paired interaction, that is, when one of the interactants started to use a given L1 pattern in the TL, such as the omission of the auxiliary in questions, then that pattern became recurrent along their exchanges, as the following example illustrates:

\section{Example 1.}

1 *CHI1: You have a girl that his hair is yellow?

$2 * \mathrm{CHI} 2$ : No, you?

$3 *$ CHI1: No.

$4{ }^{*} \mathrm{CHI}$ : You have a little girl that have flowers in his t-shirt in the in the (...)?

$5 * \mathrm{CHI} 1:$ Playground?

$6 * \mathrm{CHI} 2:$ Yes.

7 *CHI1: Yes I have it.

$8 * \mathrm{CHI} 2$ : Now you.

9 *CHI1: You have a boy that his $t$-shirt is red white and blue?

(Lázaro-Ibarrola and Hidalgo (2017))

Regarding task choice, several scholars investigating interaction using picturebased prompts have highlighted the importance of choosing age and interest-appropriate tasks, since a lack of motivation is hypothesized to lead to a higher explicit L1 use in more proficient FL learners (M. P. García Mayo \& Hidalgo, 2017; Lázaro-Ibarrola \& Hidalgo, 2017), as mentioned above.

One type of referential task commonly used in the elicitation and assessment of TL samples are picture stories (e.g., Cambridge Young Learners examinations). Rossiter et al. (2008) proposed a series of 33 evaluation criteria for the selection and creation of 
effective picture stories for L2 research, and they focussed on the nature and structure of the stories, the cultural content in them, as well as on the technical specifications of the pictures themselves. One of the aims of these authors was to outline a useful framework in order to free stories from "confusing visual elements so that participants can focus on the linguistic demands of the story" (Duff et al., 2008, p. 326). However, these authors acknowledge the fact that the efficacy of a given story might depend on the linguistic phenomenon under study, i.e., a given task might be useful in eliciting verb tenses yet fail to provide phonological evidence of certain phonemes when the key words including those phonemes are unknown by participants, and, consequently, avoided in their production.

In relation to the application of picture stories in CLI, Sánchez and Jarvis (2008) concur and note how the suitability and effectiveness of a given visual prompt ought to be assessed according to the CLI phenomenon under study. Furthermore, these authors explain how picture stories which might be deemed as unclear or troublesome might help surface different mental conceptualizations and categorizations in learners from different native-language backgrounds (Sanchez \& Jarvis, 2008, p. 330) which would otherwise remain not visible. The present study will also reflect on the possible impact of the violation of some of the criteria in Rossiter et al. (2008) on the output of students sharing their mother tongue.

Finally, according to the above, the suitability of a given visual task should also be explored in light of the amount and type of TL and CLI generated, an aspect this work attempts to provide insights on (see 5.2.1.).

\section{Research questions}

In light of previous findings, the following research questions were posited:

1. How does the L1 use in these young CLIL learners compare to results in previous interaction-based studies?

2. What forms of L1 Spanish structures are present in the English interlanguage of young CLIL learners of English when performing interactive oral tasks?

3. To what extent does the interlocutor and task factor impinge on the amount and type of CLI in young CLIL learners of English sharing Spanish as the L1?

\section{The study}

\subsection{Participants}

Twenty (20) children- eleven (11) girls and nine (9) boys - participated in the present study. They were studying their Year 3 course (8-9 years old) at a state school located in Pamplona, a city in Northern Spain. At the beginning of the study children were told that they were going to take part in a game in English. They were reassured that this was not a test or examination of any sort. Parents were informed that their children's performances would remain anonymous and limited for research purposes exclusively. Due permission was granted by both parents and the school itself.

All subjects in the study shared Spanish (or Spanish plus another language different to English) as their L1 and had limited access to English-speaking interaction 
outside their classes. All their teachers had a minimum certified $\mathrm{C} 1$ (Common European Framework of Reference for Languages, CEFR) level of English.

The proficiency of spoken English for the children in this study was based on the school's internal assessment records in the EFL subject, as well as on their performance in the diagnostic tests carried out by external examiners from the regional administration the previous year, tests which the author of this paper took part in designing and which had placed the students' oral proficiency level at pre-A1/A1. The use of additional forms of assessment, e.g., external picture-based oral proficiency A1 test such as Cambridge's YLs tests, were discarded in order to avoid an impact in terms of familiarity with the task or the interlocutor (see Chambers, Galaczi, \& Gilbert, 2012 for further information). Likewise, written placement tests, e.g., Oxford Quick Placement Test, were not considered suitable for the assessment of the oral proficiency of the students, especially given the likely mismatch in proficiency between the students' oral and written skills (Geva, 2006). Inevitably, this constitutes one limitation to the present study. Neither high nor low-performing students were included in order to guarantee maximum homogeneity in their proficiency levels.

The researcher in this study (labelled as 'expert' following the terminology frequently used in SLA research for the sake of clarity) is an L1 Spanish proficient speaker of English, he obtained Cambridge's Certificate of Proficiency in English (CEFR $\mathrm{C} 2$ ) including the maximum scoring in the oral skill, and has vast experience both as an EFL teacher and oral examiner with children and adults.

A summary of the participants' characteristics related to age and proficiency can be seen in Table 1 below:

Table 1

Participants' profile

\begin{tabular}{|r|c|}
\cline { 2 - 2 } \multicolumn{1}{c|}{} & CLIL children \\
\hline Average Age (Mean): & 8,5 \\
\hline English Proficiency & Pre A1/A1 \\
\hline School Year & Year 3 Primary education \\
\hline TL hours of exposure/Week & 10 \\
\hline
\end{tabular}

4.2. The task

The tasks at hand were designed to elicit the production of oral output. Bearing the above in mind, the tasks in the present study embed a spot-the-difference referential task within a storytelling activity, and have the following layout: one of the participants ('narrator' role) is provided with a story which had been arranged sequentially in five pictures (see Appendix A, 'Story as seen by narrator'), while their counterpart ('story builder') had 8 jumbled-up pictures which included the ones in the story plus three distracter pictures (see Appendix A, 'Story builder's sheet'), which were similar but not identical to those in the narrator's story.

One subject narrated the story to the other so that the latter had to arrange the story chronologically and leave the three wrong pictures out. A screen was placed between students in order to minimize non-verbal communication. A detailed description of the task can be seen in the following table: 


\section{Table 2}

Task description

\begin{tabular}{|c|c|c|}
\hline & \multicolumn{2}{|c|}{ Story-based Picture Placement Task } \\
\hline Student & Narrator & Story Builder \\
\hline Description & $\begin{array}{l}\text { Without showing their partner } \\
\text { their pictures, they must narrate/ } \\
\text { describe a story in order for their } \\
\text { peers to place the story in the right } \\
\text { order and leave the wrong } \\
\text { distracter pictures aside. }\end{array}$ & $\begin{array}{l}\text { Without showing their partner } \\
\text { their pictures, they must interact } \\
\text { with the narrator so that they } \\
\text { can place the story in the right } \\
\text { order and leave the wrong } \\
\text { distracter pictures aside. }\end{array}$ \\
\hline Type & \multicolumn{2}{|c|}{ Mixed: Information Gap Task + Storytelling } \\
\hline $\begin{array}{c}\text { Flow of } \\
\text { information }\end{array}$ & \multicolumn{2}{|c|}{ Two-way } \\
\hline $\begin{array}{l}\text { Exchange of } \\
\text { information }\end{array}$ & \multicolumn{2}{|c|}{ Required } \\
\hline Outcome & \multicolumn{2}{|c|}{$\begin{array}{c}\text { Closed } \\
\text { (Students had to end up arranging the story in a specific order) } \\
\text { but }\end{array}$} \\
\hline $\begin{array}{c}\text { Use of } \\
\text { language }\end{array}$ & \multicolumn{2}{|c|}{$\begin{array}{c}\text { Open } \\
\text { (The language used is unpredictable and might vary significantly) }\end{array}$} \\
\hline
\end{tabular}

\subsection{Procedure}

Data collection took place between $14^{\text {th }}$ and $23^{\text {rd }}$ April 2015. Children pairing was semirandom following alphabetical order. Before pairing the students, teachers were asked whether they reckoned any students ought (or not) to be paired in any particular way but no students were deemed particular consideration in this respect. It is noteworthy to point out that students did not know that the researcher could speak their mother tongue. While he did not say so to the children explicitly, he always addressed them in the TL so as to maximise their output in English, and students might have taken it for granted that he was a monolingual speaker of English.

The data from each participant were collected at four times as follows:

\section{Day 1: Tasks 1 and 2 (learner-expert)}

At time 1 (henceforth Day 1), every participant performed two of the story-telling tasks with the expert (the researcher). Firstly, the expert narrated the story to the learner, who had to build up the story (D1T1). This arrangement intended to create participantfriendliness so that the students could get acquainted with the task with a minimal amount of explicit instructions required.

An interlocutor frame was used to guarantee the same degree of input in all cases. Immediately after finishing D1T1, the expert and the student swapped roles and the latter acted as narrator, while the expert had to build up the story. 
Day 1. Task 1 (D1T1). Expert narrates to learner.

Day 1. Task 2 (D1T2). Learner narrates to expert.

\section{Day 2: Task 1 and 2 (learner-learner)}

Seven (7) days later, at time 2 (hereinafter Day 2) the tasks exclusively involved studentstudent interaction. Firstly, one of the students narrated the story to their story-building partner (D2T1), while they swapped roles afterwards (D2T2).

Day 2. Task 1 (D2T1). Learner B narrates to learner A.

Day 2. Task 2 (D2T2). Learner A narrates to learner B.

These tasks outlined two different participant roles - 'narrators' and 'story builders' - depending on the task at hand, as noted on the following table (3):

Table 3

Tasks and role distribution

\begin{tabular}{|c|c|c|c|c|}
\hline \multicolumn{5}{|c|}{ Story-based picture placement task } \\
\hline \multicolumn{2}{|c|}{ Day 1} & \multirow{5}{*}{$\begin{array}{l}\text { 7-day } \\
\text { interval }\end{array}$} & \multicolumn{2}{|c|}{ Day 2} \\
\hline \multirow{2}{*}{$\begin{array}{l}\text { Task } 1 \text { (D1T1) } \\
\text { Birthday Party }\end{array}$} & $\begin{array}{l}\text { Researcher as } \\
\text { narrator }\end{array}$ & & \multirow{2}{*}{$\begin{array}{l}\text { Task } 1 \text { (D2T1) } \\
\text { On a Rainy Day }\end{array}$} & $\begin{array}{l}\text { Student } \mathbf{B} \text { as } \\
\text { narrator }\end{array}$ \\
\hline & $\begin{array}{c}\text { All students as } \\
\text { story builders }\end{array}$ & & & $\begin{array}{c}\text { Student } \mathbf{A} \text { as story } \\
\text { builder }\end{array}$ \\
\hline \multirow{2}{*}{$\begin{array}{l}\text { Task } 2 \text { (D1T2) } \\
\text { The Snowman }\end{array}$} & $\begin{array}{l}\text { All students as } \\
\text { narrators }\end{array}$ & & \multirow{2}{*}{$\begin{array}{l}\text { Task } 2 \text { (D2T2) } \\
\text { The Toyshop }\end{array}$} & $\begin{array}{l}\text { Student } \mathbf{A} \text { as } \\
\text { narrator }\end{array}$ \\
\hline & $\begin{array}{l}\text { Researcher as } \\
\text { story builder }\end{array}$ & & & $\begin{array}{c}\text { Student } \mathbf{B} \text { as story } \\
\text { builder }\end{array}$ \\
\hline
\end{tabular}

\subsection{Data coding}

All of the participants' interactions were coded independently by the author of the paper and an additional researcher, and subsequently compared. Inter-rater reliability was calculated using simple percentage agreement, which resulted in $92 \%$. Any remaining discrepancies were solved individually on a case-by-case basis.

\subsubsection{L1 use}

Different scholars have established different categorisations in order to code lexical CLI in their research (e.g., Alegría de la Colina \& García Mayo, 2009; Hammarberg, 2001; Ringbom, 2001). After identifying the instances of such items in our transcriptions, we found out the students' explicit L1 use fit within the following two categories: 'Edit' and 'Insert: explicit elicit' (Hammarberg, 2001).

In the present study, the former covers forms of self-repair (similarly coded as 'discourse markers' in Alegría de la Colina and García Mayo (2009)), while the latter refers to explicit switches in order to elicit the English expression from their interlocutor 
(coded as 'Vocabulary: deliberation over vocabulary' in Alegría de la Colina and García Mayo (2009)).

These functions are illustrated in the following examples from our participants:

EDIT

Example 2.

1 *CHI1: The boy put his ...erm... Ay! (English: Oh!) His... Jacket and the girl is putting, erm... too the raining boots, pink. (...) I do next? [EDIT]

\section{INSERT: EXPLICIT ELICIT}

Example 3.

1 *CHI1: And, how do you say 'van anciano' (English: 'go grandfather')? [INSERT: EXPLICIT ELICIT]

\subsection{2. $\mathrm{L} 1$ structures}

The present study uses the term ' $\mathrm{L} 1$ structures to refer to instances of L1 Spanish morphosyntax emerging from the data, i.e., underlying Spanish morphology and syntax features seeping through the participants' output in the form of ungrammatical English, as well as lexical CLI other than explicit L1 use.

With the aim of adding insights into the research questions, all transcriptions were coded using a scheme that emerged from the data, which led to the categorisation below, illustrated by examples from the present study.

Language tokens which have already been categorised in the literature as developmental errors in the L1 acquisition of English have not been included in our results, such as the following examples found in the data:

Example 4.

1 *CHI1: The girl put the eyes of the snowman. ${ }^{2}$ (Dulay \& Burt, 1974, p. 134)

\section{Example 5.}

1 *CHI1: And he eat a banana. ${ }^{3}$ (Dulay \& Burt, 1974, p. 132)

Likewise, ungrammatical instances which would entail an ungrammatical form if translated into Spanish have also been discarded:

Example 6.

\footnotetext{
${ }^{2}$ Count for Structure 6: (NP-Aux) - V + ing - (Infin)-Nop-Prep-NP/NP-NP.

${ }^{3}$ Error count for structure 1: NP - V- Pron.
} 
1 *CHI1: Girl and boy are imagine in the toyshop.

(Spanish: 'Niña y niño están imagina en la tienda de juguetes. ')

Example 7.

1 *CHI1: Boy is take off the... jacket.

(Spanish: 'Niño está quita la ... chaqueta.')

Example 8.

1 *CHI1: You doesn't say the supermarket.

(Spanish: 'Tú no dice el supermercado.')

Thus, only those instances of ungrammatical English whose word-for-word translation into Spanish would provide a grammatically correct language token have been included. Translations for each example have consequently been provided.

The bespoke classification below encompasses all such instances, some of which fully match well-documented CLI phenomena common in the acquisition of L2 English by non-native learners (Examples 12, 13). However, the data analysis also revealed language tokens which blended features of already reported CLI phenomena with morphosyntactic characteristics unique to the Spanish language (Example 6). In all cases, a reference will be provided.

(i) Elision. This category comprises the omission of single terms such as dummy subjects, prepositions, subjects, as well as the elision of multiple words within a sentence (coded as 'other forms: expanded):

Example 9.

$1 * \mathrm{CHI} 1$ : In one picture are balloons black and the other red [Elision: Dummy subject] (Spanish: 'En un dibujo hay globos negros y los otros rojos.')

Example 10.

$1 * \mathrm{CHI} 1$ : Putting the hat [Elision: preposition]

(Spanish: 'Poniéndo (se) el sombrero.')

Example 11.

$1 * \mathrm{CHI} 1$ : Is jumping in the bed? [Elision: subject]

(Spanish: ‘Está saltando en la cama?’)

Example 11 features declarative word order, no inversion and no fronting, i.e., a Stage 2 question structure according to the L2 acquisition of English questions in Pienemann, Johnston and Brindley (1988). As opposed to the French L1 subjects in Pienemann et al's (which would correspond to 'He is jumping in the bed?', by contrast, Example 11 also 
includes subject omission, which could constitute a variation of Stage 2 questions specific to Spanish L1 learners.

Example 12.

1 *CHI1: About that they don't have (...) [Elision; other forms: expanded]

(Spanish: 'Sobre que no tienen (...).')

(ii) L1 plural forms. Here we include the pluralisation of terms which only exist in its singular form in English, and they were found in irregular plural words in English (i.e., not ending in ' $s$ ') and singular numeral determiners:

Example 13.

$1 *$ CHI1: Childrens [L1 plural forms: double plural]

(Spanish: 'Niños(s). ')

Example 14.

1 *CHI1: 'Ones balloons' [L1 plural forms: Singular numeral determiner]

(Spanish: 'Uno(s) globos.')

(iii) Overgeneralisations. This concept refers to the ungrammatical use of terms or structures whose meaning or usage is more limited or less general than stated. In the present study it includes gender nouns, particles 'no' or 'yes' as substitutes for contracted forms and possessives:

Example 15.

1 *CHI1: The two boys (girl and boy) are... are... bored [Overgeneralisation: gender] (Spanish: 'Los dos niños (masculine) están... están ... aburridos.')

Example 16.

$1 * \mathrm{CHI} 1:$ Here are two balloons and here no [Overgeneralisation: negation particle] (Spanish: 'Hay dos globos y aqui no.')

Example 17.

$1{ }^{*} \mathrm{CHI} 1:$ Two children and his (their) father ${ }^{4}$ [Overgeneralisation: possessive] (Spanish: 'Dos niños y su ('su': 'his/her' but also 'their') padre.'

\footnotetext{
${ }^{4}$ Possessive Determiners, Stage 2: Emergence on French-speaking students (White, 1998).
} 
(iv) Additional types of transfer. Here are included further instances of CLI spotted in our data, including subject-adjective inversion, transfer of L1 prepositions and syntax at phrase level, subject-verb inversion in questions, circumlocution and calques ${ }^{5}$ :

Example 18.

$1 * \mathrm{CHI}$ : Balloons black and the other red $^{6}$ [Additional: subject-adjective inversion] (Spanish: 'Globos negros y los otros rojos.')

Example 19.

$1 * \mathrm{CHI} 1$ : In the floor [Additional: L1 preposition]

(Spanish: 'En el suelo.')

Example 20.

$1 * \mathrm{CHI} 1:$ He is looking for the window to the rain [Additional: L1 syntax]

(Spanish: 'Él está mirando por la ventana la lluvia.')

Example 21.

1 *CHI1: There are two balloons flying? [Additional; subject-verb inversion: questions] (Spanish: ‘Hay dos globos volando?’)

Example 22.

1 *CHI1: Balls of colours (used to mean 'balloons') [L1-structured circumlocution] (Spanish: 'Bolas de colores.')

Example 23.

$1 *$ CHI1: More long [Calque]

(Spanish: 'En un dibujo hay globos negros y los otros rojos.')

\footnotetext{
${ }^{5}$ In the present study 'circumlocution' refers to roundabout expressions in the TL which, translated wordfor-word would lead to a similar expression in the L1, i.e., it is not possible to determine whether the learner knows the specific term in the L1. 'Calques' in this study includes borrowed, literal word-for-word translations.

${ }^{6}$ Error count for structure 2: det-Adj-N (Dulay \& Burt, 1974).
} 


\section{Results}

The present section provides an answer to the research questions above by dissecting explicit L1 use, L1 structural transfer, and by analysing the possible effect of the interlocutor and task variables in the students' CLI. An additional subsection will cover observations of certain phenomena relevant to CLI in the learners' production. Due to the small sample sizes, we resorted to the Wilcoxon signed-rank test (a non- parametric equivalent alternative to the matched-pairs t-test). Significance level was fixed at $p=0.05$. Quantitative analyses were carried out using SPSS Version 24.

\subsection{L1 use}

Regarding our first research question, explicit L1 use among the students in the present study was nearly inexistent, even lower than the -already low - rates in similar previous work on CLIL YLs (e.g., 4.8\% for Year 3 CLIL learners in García Mayo \& Hidalgo, 2017) and in line with the low percentages reported in the EFL beginners in LázaroIbarrola and Azpilicueta-Martínez (2015), that is, 0,51\%.

\section{Table 4}

L1 use in children narrating to expert:

\begin{tabular}{|c|c|c|c|}
\hline Day / Task & Utterances & L1 use & Percentage \\
\hline D1T2 & 494 & $6\left(\mathrm{I}: \mathrm{EE}^{*}\right)$ & $1.21 \%$ \\
\hline
\end{tabular}

Table 5

L1 use in children narrating to a peer:

\begin{tabular}{|c|c|c|c|}
\hline Day / Task & Utterances & L1 use & Percentage \\
\hline D2T1 & 203 & $\begin{array}{c}3 \\
(2 \mathrm{I}: \mathrm{EE}+1 \text { EDIT })\end{array}$ & $1.47 \%$ \\
\hline D2T2 & 329 & $\begin{array}{c}7 \\
(2 \mathrm{I}: \mathrm{EE}+5 \mathrm{EDIT})\end{array}$ & $2.12 \%$ \\
\hline TOTAL & 532 & $\begin{array}{c}10 \\
(4 \mathrm{I}: \mathrm{EE}+6 \mathrm{EDIT})\end{array}$ & $1.87 \%$ \\
\hline
\end{tabular}

\section{*I:EE:INSERT: EXPLICIT ELICIT}

It is worth noting how, even at such low rates, students seem to diverge in the type of L1 they resort to depending on the interlocutor at hand, i.e., all of the L1 items uttered when interacting with an expert were forms of I:EE, that is, translation requests (Example 19), whereas most of the L1 terms displayed when interacting with a peer where mere (lexically meaningless) interjections of the '¡Ay!' (English 'Oh!') type.

\section{Example 24.}

$1{ }^{*} \mathrm{CHI} 1$.... the girl is, erm ... how do you say 'quitar'?

[INSERT: EXPLICIT ELICIT] 
Evidently, this appears to relate to the fact that they might not regard their partners as a source of lexical knowledge in the same way as they do an adult pretend monolingual speaker of English. In this respect, even the I:EE raised in peer-peer interaction appeared to be also directed at the researcher, who was present while recording the interactions. This fact casts doubt as to whether participants would have resorted to the L1 explicitly or would have opted for other means of expression (e.g., circumlocution) to the same degree had the researcher not been present during their peer-peer interactions.

The extremely low explicit L1 use rates in this work call into question the extent to which explicit L1 use necessarily declines as proficiency in the TL increases (AgustínLlach, 2009; Herwig, 2001; Navés et al., 2005; Serra, 2007), since rates were still lower than the high-school students analysed in M.P. García Mayo and Lázaro-Ibarrola (2015b). As is the case with recent research in which older, more proficient CLIL groups resorted to their L1 more frequently (e.g., M. P. García Mayo \& Hidalgo, 2017; M.P. García Mayo \& Lázaro-Ibarrola, 2015b), this study contributes to support the pivotal role of tasks influencing explicit L1 use at cognitive and motivational levels impinging on explicit L1 use.

\subsection{L1 structures}

With regard to our second and third research questions, instances of structural transfer through the students' English were far more copious than explicit L1 use, as may be observed in the tables below.

\section{Table 6}

L1 structures: children narrating to expert.

\begin{tabular}{|c|c|c|c|}
\hline Day / Task & Utterances & Instances of non-explicit CLI & Percentage \\
\hline $\begin{array}{c}\text { D1T2 } \\
\text { (20 narrators) }\end{array}$ & 494 & 47 & $9.51 \%$ \\
\hline
\end{tabular}

Table 7

L1 structures: children narrating to children.

\begin{tabular}{|c|c|c|c|}
\hline Day / Task & Utterances & Instances of non-explicit CLI & Percentage \\
\hline $\begin{array}{c}\text { D2T1 } \\
\text { (10 narrators) }\end{array}$ & 203 & 46 & $22.66 \%$ \\
\hline $\begin{array}{c}\text { D2T2 } \\
\text { (10 narrators) }\end{array}$ & 329 & 37 & $11.25 \%$ \\
\hline TOTAL D2 & 532 & 83 & $15.60 \%$ \\
\hline
\end{tabular}

Table 8

L1 structures: children narrating (total).

\begin{tabular}{|c|c|c|c|}
\hline Day / Task & Utterances & Instances of non-explicit CLI & Percentage \\
\hline TOTAL & 1026 & 130 & $12.67 \%$ \\
\hline
\end{tabular}

As may be observed in Tables 6 and 7 there was a higher rate of non-explicit CLI when students interacted with a peer. However, differences were non-significant $(Z=-1.218$; $p=0.223)$. 
It is pertinent to highlight how D2T1 (Appendix A) brought about the highest percentage of non-explicit CLI, more than doubling the rates in the other two tasks. A closer look at the data reveals how students appeared to struggle to convey the meaning of seemingly unclear differences, such as the ones in picture 1 . Thus, these pictures might violate Criterion 28 (“Are actions clear?") in Rossiter et al. (2008), and will be further considered in 5.2.1.

We then compared the results of the students acting as narrators (N: 130) with the same students performing the task as story builders (N: 67), something which brought about significant differences $(Z=-2.361 ; p=0.018)$. Nevertheless, we should not take these results at face value, since narrators nearly doubled the amount of output produced by story builders (1026 vs 550 utterances).

Finally, and even though it did not constitute the main focus of this study, possible differences regarding the interlocutor factor between the students performing the task as story builders (N: 27, D1; N: 40, D2) were also compared, again yielding non-significant results $(Z=-0.742 ; p=0.458)$.

The following table subcategorises the results regarding the classification in 4.4.2. when children acted as narrators (all tasks).

Table 9

L1 structures: children narrating (total). Subcategories.

\begin{tabular}{|c|l|c|c|}
\hline Structural transfer & \multicolumn{1}{|c|}{ Subcategory } & $\mathrm{N}$ & Percentage \\
\hline \multirow{5}{*}{ Elision } & Dummy subject & 10 & $7.69 \%$ \\
\cline { 2 - 4 } & Preposition & 21 & $16.2 \%$ \\
\cline { 2 - 4 } & Subject & 14 & $10.8 \%$ \\
\cline { 2 - 4 } & Other forms: expanded & 3 & $2.31 \%$ \\
\hline \multirow{3}{*}{ Plural forms } & Double plurals & 3 & $2.31 \%$ \\
\cline { 2 - 4 } & Adjectives & 1 & $0.77 \%$ \\
\hline \multirow{3}{*}{$\begin{array}{c}\text { Additional } \\
\text { Types of transfer }\end{array}$} & Gender & 18 & $13.8 \%$ \\
\cline { 2 - 4 } & Particles 'no' and 'yes' & 3 & $1.54 \%$ \\
\cline { 2 - 4 } & Possessives & 11 & $2.31 \%$ \\
\hline & Subject-adjective inversion & 9 & $6.46 \%$ \\
\cline { 2 - 4 } & L1 prepositions & 12 & $6.92 \%$ \\
\cline { 2 - 4 } & L1 syntax (phrase level) & 1 & $0.77 \%$ \\
\cline { 2 - 4 } & Subject-verb inversion (questions) & 4 & $3.08 \%$ \\
\cline { 2 - 4 } & L1-structured circumlocution & 18 & $13.8 \%$ \\
\hline
\end{tabular}

In order to maximise TL use by the students, the usual response from the expert when asked to translate a given term was to pretend to misunderstand the speaker. This fact might have led to a decline in the number L1 items on the subjects' part, and, possibly, to a higher rate of structural transfer given their need to look for alternative means of expression. Curiously, in one case did the researcher provide an answer to one of those questions, and it appeared to immediately trigger a higher number of translation requests - and, perhaps, to a lower effort to convey meaning using their own English words within that dyad: 
Example 25.

1 *CHI1: In the... in the... how do you said... 'carro' ('trolley') (looking at researcher)?

$2 *$ RES: Trolley?

$3 * \mathrm{CHI} 1: \quad$ In the trolley?

4 *CHI2: $\quad$ No.

5 *CHI1: $\quad$ Where?

6 *CHI2: $\quad$ How do you say 'detrás' ('behind')'? (looking at researcher)

7 *CHI1: $\quad$ Behind.

8 *CHI2: $\quad$ Behind the children.

$9 *$ CHI1: $\quad$ Breads.

$10 * \mathrm{CHI} 2: \quad$ Ah...

$11{ }^{*} \mathrm{CHI} 1: \quad$ In the third picture, in the fourth picture there, there are in the bookshop, the dad is reading a book and the two childrens are... erm... how do you say 'agotados' ('drained')?

*RES: Researcher

As regards individual differences there was a great degree of variability among participants, including one subject producing no visible instances of L1structural transfer whatsoever, while another single participant displayed 24 language tokens containing L1 structural transfer.

5.2.1. Insights from the students' interlanguage

In order to supplement the results in the previous subsections with more qualitative information, what follows next are observations from the participants' production which were deemed of particular interest.

One common form of non-explicit CLI among the students in D1T1 (see Appendix A) was the following recurrent construction from different students interacting with the expert:

Example 26.

$1 * \mathrm{CHI1:} \quad$ That, erm... in the sofa, $u$, up the sofa are two balloons.

Example 27.

1 *CHI1: $\quad$ They are, there are balloons, erm... erm... erm.... erm... are more up of the sofa?

Students appear to share their spatial conceptualization leading them to resort to the same bespoke CLI alternative via 'up' or 'up of', which a monolingual speaker of English would have possibly discarded in favour of 'over'. Further research would be needed in order to check the extent to which learners from different L1 backgrounds categorise and articulate this type of event in English. 
In 4.4.2. (iii) we have noted how the overgeneralisation of gender ('boys' including both genders in Spanish 'chicos') was present across the data. However, a closer look at this phenomenon reveals how task design appears to interact with lexical CLI particularly when word choice implies a significant difference between the pictures and the distractors. Example 28 was spotted in D1T2 (see Appendix A), a story in which both children are visibly performing the same action in all pictures (i.e., it was unimportant to specify who did what):

\section{Example 28.}

$1 * \mathrm{CHI} 1: \quad$ In the first picture... two boys are playing in the floor with the snow... and next there is a grandpa sitting in a bank.

Example 29, by contrast, belongs to D2T1, a story in which the boy and the girl carried out different actions (upon which hinged some of the differences between the 'right' pictures and the distractors):

\section{Example 29.}

1 * CHI1: $\quad$ Erm ... the ... boy and a girl are putting the ... boots.

Note how the child in 28 does not 'bother' to differentiate who is doing what, and so she incurs in a form of ungrammatical English with no undesirable consequences. D2T1, however, appears to 'force' students to be more accurate and avoid such overgeneralisation (see 4.4. Data Coding) if they are to succeed in the task. As a matter of fact, not a single student referred to 'boys' in any of the pictures in D2T1, and, when they did, they immediately self-corrected, as the example below illustrates:

Example 30.

$1 * \mathrm{CHI} 1: \quad$ Erm .... there are two boys in... there is a girl and a boy... seeing the bad day that... is in that moment.

In their study, Lázaro-Ibarrola and Hidalgo (2017) had reported non-explicit CLI never leading to recasting or explicit corrections. While this phenomenon was also observed in the present work, occasionally confirmation checks or clarification requests were needed occasionally:

\section{Example 31.}

1 *CHI2: $\quad$ Yes. They are happy, they are sad?

$2 *$ CHI1: $\quad$ Erm... sad? [Confirmation check]

Likewise, we believe the students' sharing of the L1 might, in turn, be acting as a catalyst for the imitation of L1 structures reported by Lázaro-Ibarrola and Hidalgo (2017), since such imitation was also spotted right across our data. Note the absence of verb fronting in the questions in examples 31 and 32, belonging to the same dyad in two consecutive tasks: 
$1 * \mathrm{CHI}$ : $\quad$ Student $B: \quad$ In the picture of the supermarket they are a... bread? Or, erm.... le .... Lettuce?

$2 * \mathrm{CHI}$ : What? [Clarification request]

$3 * \mathrm{CHI1}$ : $\quad$ In the picture of the supermarket they are bread? Or... in ... or, or ... erm... or lettuce?

D1T2 (Appendix A) yielded the lowest rate of non-explicit CLI, i.e., the highest percentage of grammatically correct utterances in the TL. We believe the results in D1T2 might be related to the fact that the story in it complied with key criteria in Rossiter et al. (2008) (such as clarity of the pictures and the logical sequence of the story) to a higher degree than the rest of tasks, and such clarity might have brought a less demanding, factual type of discourse on the students' part. What follows are two typical samples of the participants' production in D1T2:

Example 33.

1 *CHI1: $\quad$ The girl is putting the eyes.

2 *RES: $\quad$ Very good! And? What happens after that?

3 *CHI1: $\quad$ They are thinking about and the old man is looking for her and is eating a banana.

4 *RES: $\quad$ Is the snowman finished?

$5 * \mathrm{CHI} 1: \quad$ Yes.

6 *RES: $\quad$ In picture number four?

7 *CHI1: $\quad$ No.

8 *RES: $\quad$ What's missing?

9 *CHI1: $\quad$ The nose, and the scarf.

10 *RES: Oh, very good!

11 *CHI1: And the hat.

12 *RES: Ok! Excellent! How does the story finish, (student's name)?

13 * CHI1: $\quad$ Then they do the snowman and the old man is very happy.

Example 34.

$1 * \mathrm{CHI1}$ In the third the girl is putting the eyes in...to the snowman and the boys is putting the arms.

2 *RES: $\quad$ That's very good, (student's name)! What happens after that?

3 *CHI1: $\quad$ In the fourth picture there are, the children make the snowman and they are thinking what more they can put to the snowman and the father is... looking, eating the banana.

Note how the structure and clarity of the story trigger a type of language among students which is simple, present-tense based, yet CLI-free to a high degree. Compare examples 33 and 34 to the following extract from D2T1: 
$1 * \mathrm{CHI} 1: \quad H e r e$ two, two boys, one girl, one girl and two, and one boy, is raining and he, he looking of the window.

2 *CHI2: $\quad$ Erm... the ... are two pictures... are two pictures the same. One, the ... first picture it ha, the boy it's sad and the girl is sad, and the second is with the... with the... with the mouth a little bit... erm ... a little bit... straight.

3 * CHI1: $\quad$ Yes, is that.

As opposed to examples 33 and 34, the case in 35 illustrates how the lack of clarity between the pictures, i.e., the violation of Rossiter et al's (2008) Criterion 28 ("Are actions clear?") has generated the need in the story builder to negotiate with his interlocutor and attempt to clarify that two of his pictures were similar and it was hard for him to odd the wrong one out. In addition, while the distractor depicted a character in a mood beginner students are readily familiar with, 'being sad', the right picture included two children who could be expressing a range of more complicated, less clear mindsets, such as being baffled, scared, surprised or embarrassed. We believe this need to convey a more complex meaning might have impinged on the amount of non-explicit CLI in our participants.

Interestingly, D2T2 included a slight violation of another of the criteria in Rossiter et al's (2008) Criterion 6: "Are the illustrations free of surreal or illogical elements?". A significant portion of students took it for granted that picture 3 would be the one depicting the girl next to her daddy, since such was the position those characters appeared on the preceding and following scenes (as various students reported later). However, participants refraining from making that assumption tended to resort to either of the following two strategies:

Example 36.

$1{ }^{*} \mathrm{CHI} 1: \quad$ What, in what order are the children? First the boy or first the girl?

2 * CHI2: $\quad$ First the boy. Then they go to the library. The... children are bored, and the father is... is... see some a book.

\section{Example 37.}

$1{ }^{*} \mathrm{CHI} 1: \quad$ And the boy is in the left or... in the right?

$2 * \mathrm{CHI}$ : $\quad$ In the... In the right.

Example 37 might appear closer to what a monolingual adult speaker of English would actually produce, since differences between those pictures hinge on a physical horizontal position, i.e., left-right, not ordinal or up-down. Surprisingly, example 36 proved to be much more effective in having the story builder choosing the right picture, whereas the more canonical, perhaps more CLI-free example 37 often led to confusion and the need to negotiate further again.

Consequently, examples such as picture 3 in D2T2 might be promoting L1structured output rather than structures closer to the norm in the TL since such language choice might be i) more efficient task-wise and also ii) more similar to the students' L1. 
In other words, in the example above it is both easier and more effective to use L1structured TL than to try to use language closer to the TL standard.

One possible explanation for the phenomenon above could be the possibility that children assumed 'first' would mean 'first on the left', the same pattern they follow when they read texts, while those opting for the second strategy (37) failed to use relative positions 'left' or 'right' efficiently, due to their lack of fixed reference points (e.g., on the father's right). This is confirmed in the following example by another dyad:

Example 38.

$1 * \mathrm{CHI} 1: \quad$ The girl is... at the ... first or at the right?

$2 * \mathrm{CHI}$ : $\quad$ Erm... the girl is... on the... right.

$3 * \mathrm{CHI} 1: \quad$ Fourth, please.

It is worth noting how none of the participants resorted to prepositions of place in order to clarify picture 3 in D2T2, i.e., "Who is next to daddy?" or "Is the boy between daddy and the girl?", even though they were familiar with them.

As a whole, this subsection has attempted to supplement the results in 5.2. by providing qualitative insights on the intricacies and complexities of the students' output, particularly in the ways task design (e.g., the violation of the criteria in Rossiter et al, 2008) interacts with CLI, and, in turn, the production in the TL. 


\section{Discussion and conclusions}

Results in this study have shown that explicit L1 use was extremely low, and values were similar irrespective of whether children interacted with a peer or an expert speaker of the TL. Thus, they concur with previous research questioning the inverted correlation between proficiency in the TL and explicit L1 use (e.g., Lázaro-Ibarrola \& AzpilicuetaMartínez, 2015; Sánchez, 2003; Sanz, 2000). We believe these results are related to the factors mentioned in García-Mayo and Hidalgo (2017), that is, "learner motivation, task complexity, task repetition and instructional setting" (M. P. García Mayo \& Hidalgo, 2017, p. 133).

Regarding motivation and explicit explicit L1 use, the fact that the children in the study did not know the expert could speak Spanish ${ }^{7}$ might have led them to assume he would not understand any language other than English. If this were true, it might have impinged on their explicit use of the L1, and, consequently, might have triggered a higher use of roundabout expressions or L1 avoidance. This 'perceived monolingualism' within the interlocutor factor is a variable which ought to be explored in relation to L1 use and L1 CLI in future studies, given its profound pedagogical implications.

Our results also appear to have implications regarding the ways task complexity, and the suitability and effectiveness of the visual prompts, affect explicit L1 use. The arrangement of the activity in dyads, and the students' need to interact orally in order to arrange the story in the right order brought about no visible off-task communication, a type of interaction which had revealed a significantly higher number of L1 items in Broner (2001).

Overall, our findings regarding explicit L1 use should push those teachers and stakeholders refraining from interactive activities with YLs on the grounds that these lead to less TL use.

By contrast, non-explicit CLI appeared to be much more noticeable across the data. Structural transfer was consistently present irrespective of the task or interlocutor at hand, therefore constituting a characteristic element of learners' TL production at this level. It is relevant to highlight that there were instances of the students' interlanguage which correspond with the same processes in monolingual English-speaking children, such as the overgeneralisation of the negative particle 'no' (Schumann, 1979; Wode, 1978).

On the other hand, our findings also warn about the possible fossilization of ungrammatical L1 structures in the TL when level-matched students interact in pairs. In this respect, some of the type and frequency of lexical CLI appears to be highly taskdependent, as noted in 5.2.1., naturally forcing the students to be more accurate in their language choice without the need of a pedagogical intervention.

Results in the present work also led us to believe that task design, layout and complexity might also influence structural CLI. Some of the findings in 5.2.1. suggest features such as the degree of clarity or logic within a story might lead to the expression of more complex representations for which language in the students may be lacking and,

\footnotetext{
${ }^{7}$ Find the raison d'être for this 'pretended monolingualism' on 5.2. 'L1 Structures'.
} 
in turn leading them into higher non-explicit CLI rates. In other words, when students share the L1, certain task features (e.g., the violation of some of the criteria in Rossiter et al, 2008) might lead them into resorting to L1-structured TL rather than structures closer to the norm by being more effective task and communication-wise.

We are, therefore, presented with the pedagogical challenge of designing and finding age, level and interest-appropriate tasks which boost students' use of the TL (e.g., by pushing them into 'on-task' interaction) in paired interaction, that is avoiding tasks which might be too simple or not interesting enough, as García Mayo and Hidalgo (2017) forewarn with some of their older CLIL students. More research is needed however, in order to strike the right balance between tasks which are interesting and cognitively demanding enough for the students, yet not so ambitious that they prevent learners from using the TL structures needed to perform them successfully.

As a result, findings in this study pave the way for further research analysing the possibility of a negative correlation between explicit L1 use and L1 structural transfer.

As a whole, given the increasing questioning on the role of L1 in L2 learning regarding both teacher-learner and peer interaction (Cook, 2001; Turnbull \& Arnett, 2002; Wells, 1999), the findings in the present study confirm that L1 terms are used scarcely and wisely in both interaction modes (child-child and child-expert), but warn us about the possibility that structural transfer could be reinforced when interaction occurs among peers at low levels of proficiency. Since such transfer might be triggered by learners' perception of partial similarities between the L1 and the L2, and may be especially difficult to overcome when learners are frequently in contact with peers making the same errors (Lightbown \& Spada, 2006), this paper advocates the use of task designs in which learners' attention is also drawn to form, even at beginner level, and calls for further research on the developmental L2 readiness of learners at this level and age to benefit effectively from such practices. 
APPENDICES

APPENDIX A - THE TASKS

D1T1: Birthday Party

Story as seen by narrator, showing correct version:

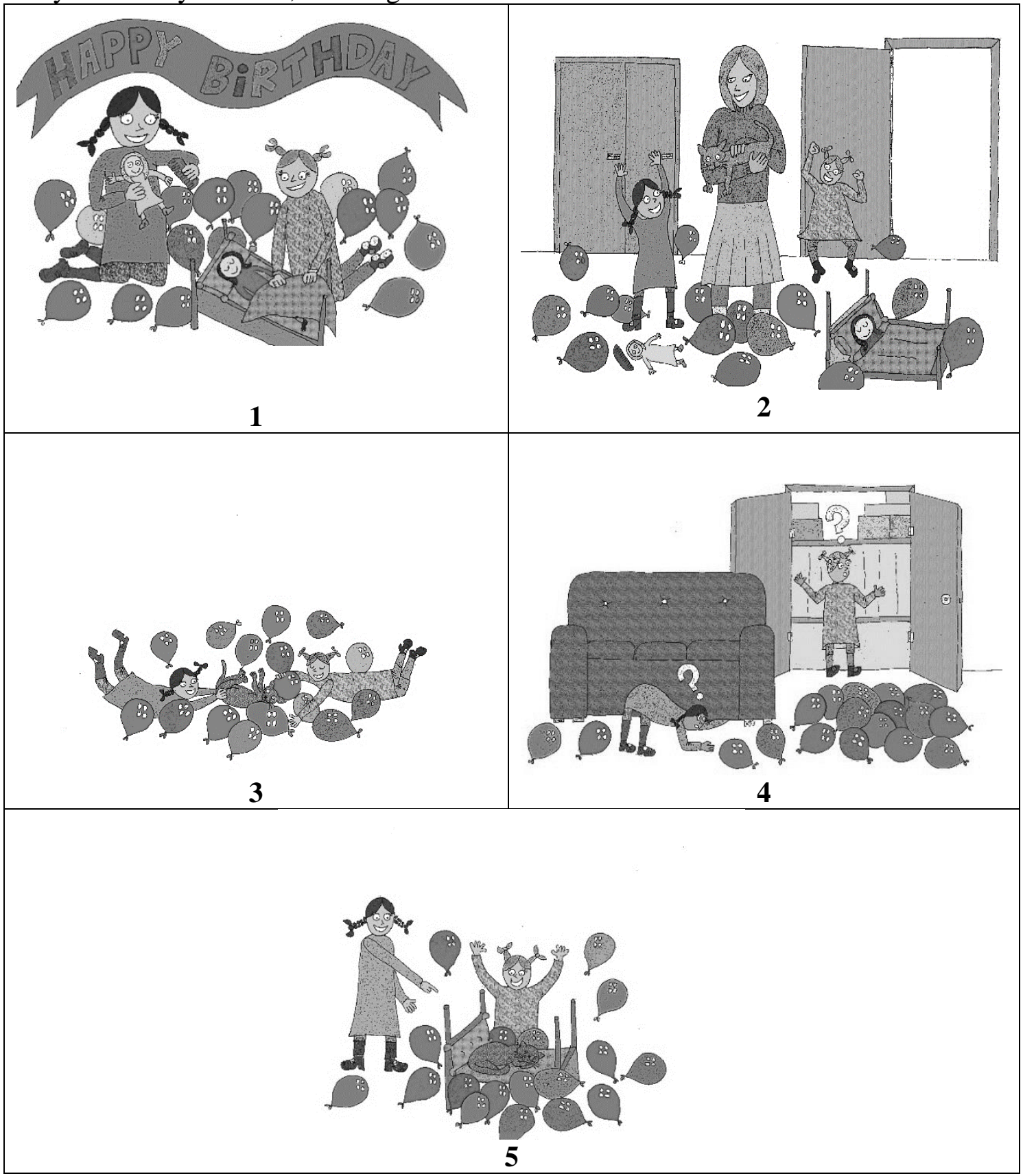


Story builder's sheet, showing pictures in random order plus 3 distractors

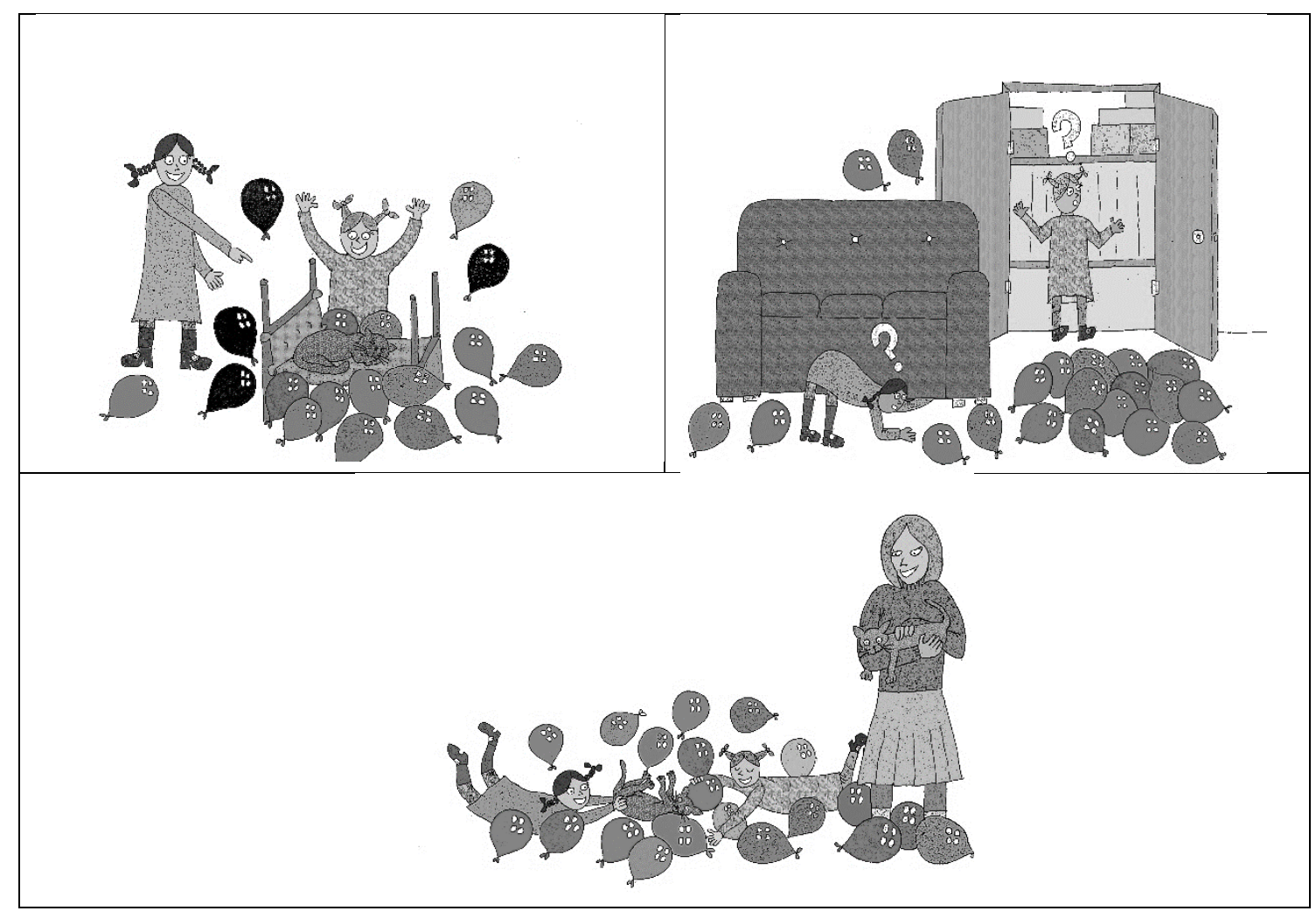


D1T2: The Snowman

Story as seen by narrator, showing correct version:

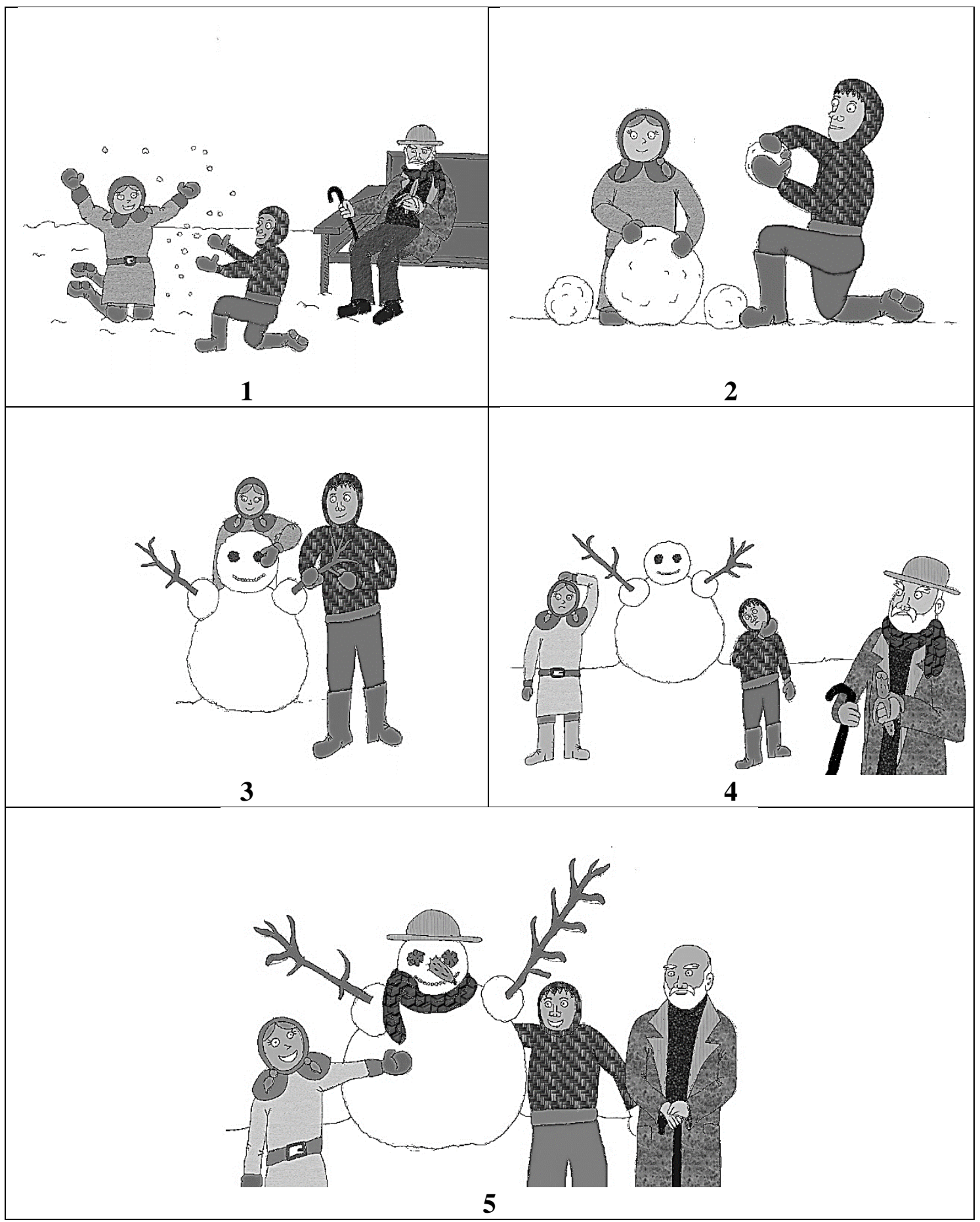


Story builder's sheet, showing pictures in random order plus 3 distractors

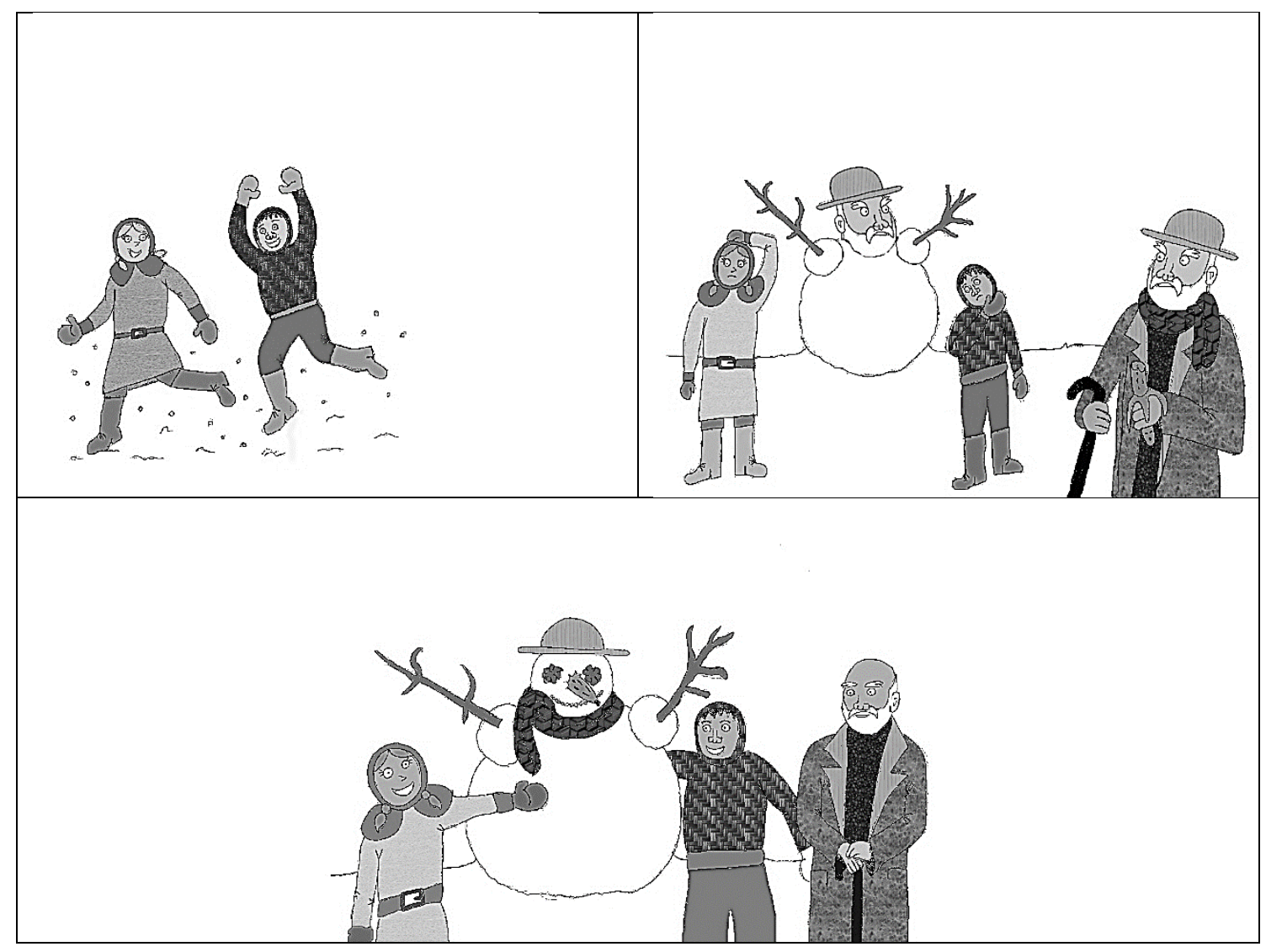


D2T1: On a Rainy Day

Story as seen by narrator, showing correct version:

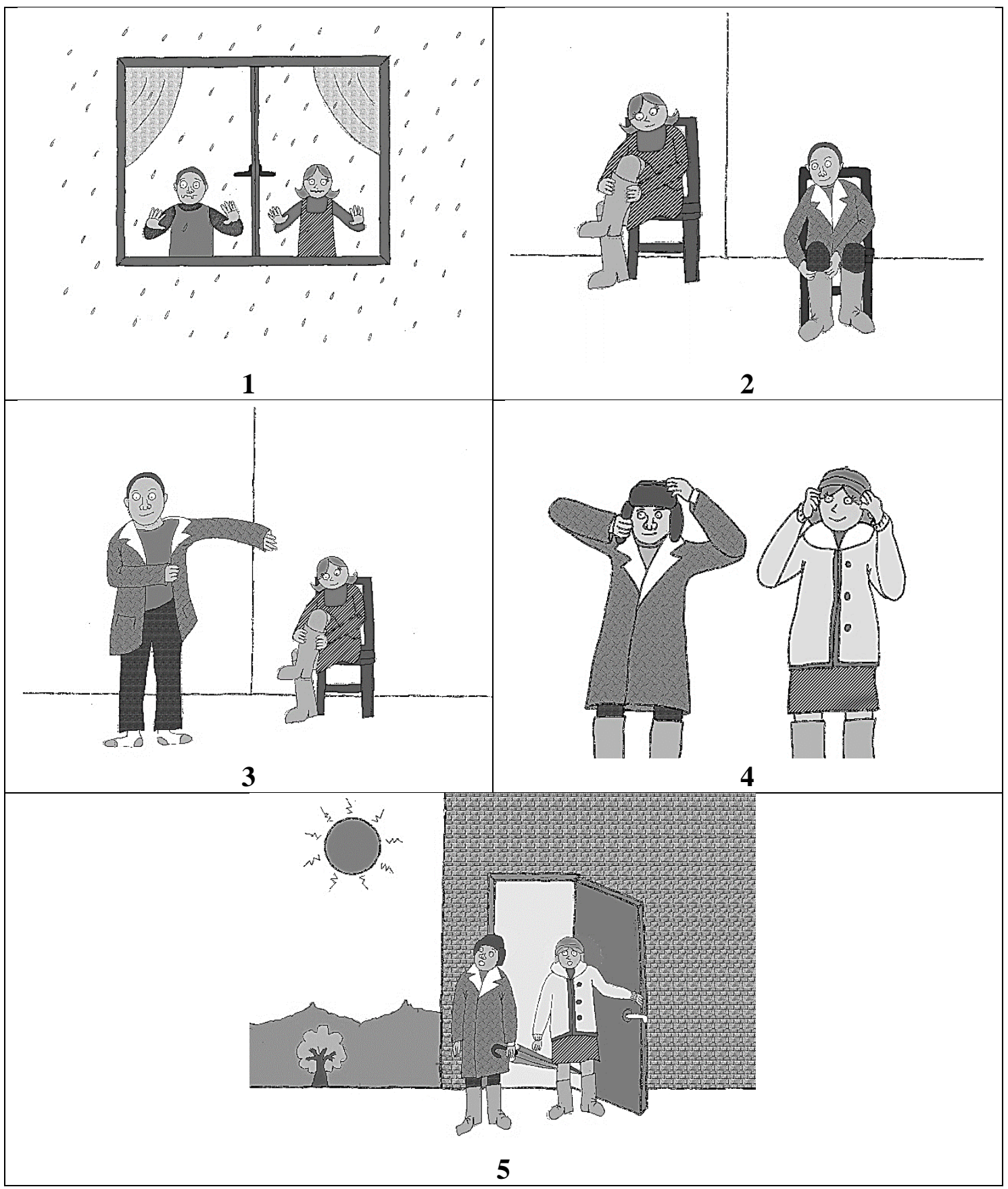


Story builder's sheet, showing pictures in random order plus 3 distractors

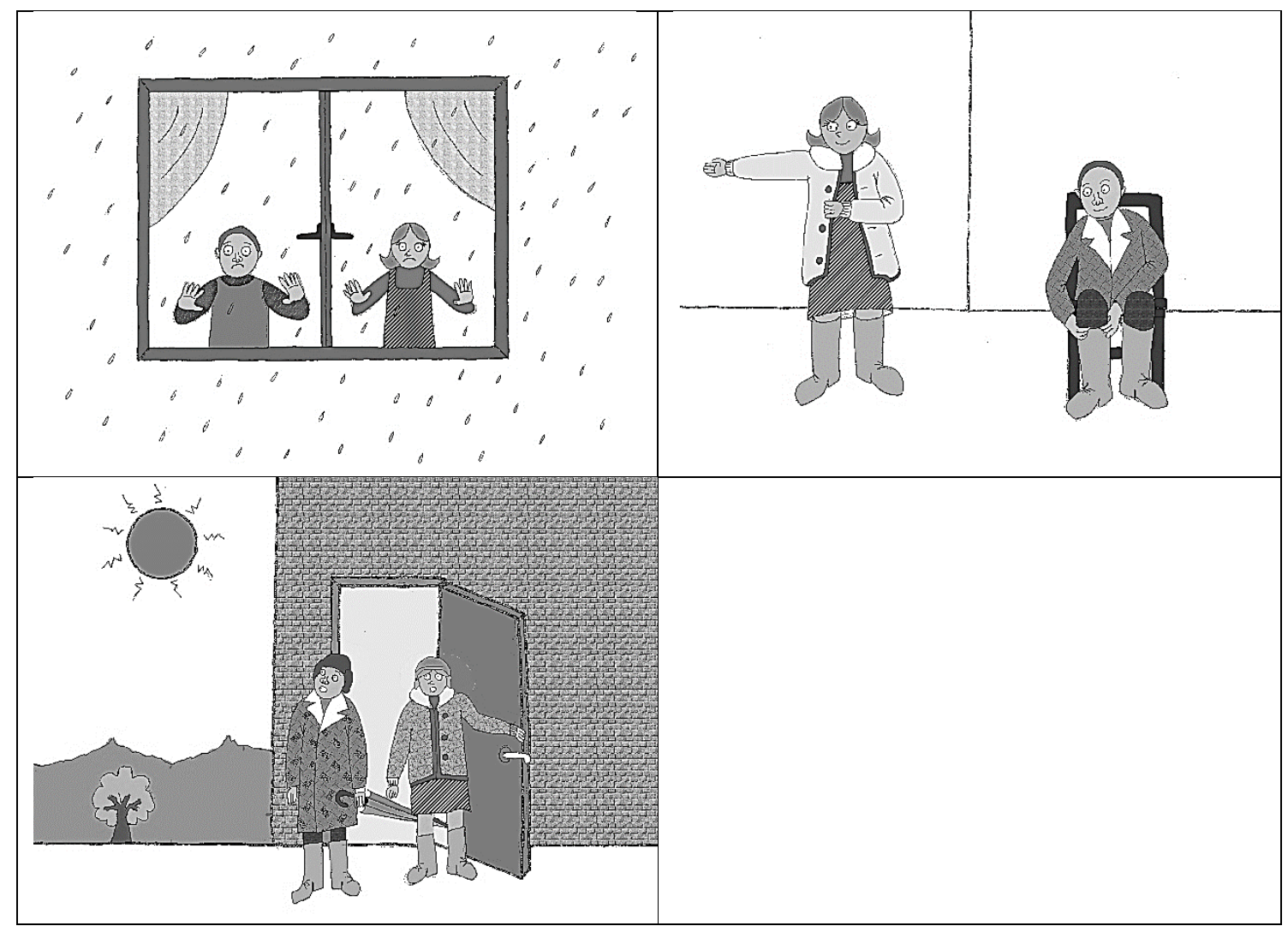


D2T2: The Toyshop

Story as seen by narrator, showing correct version:

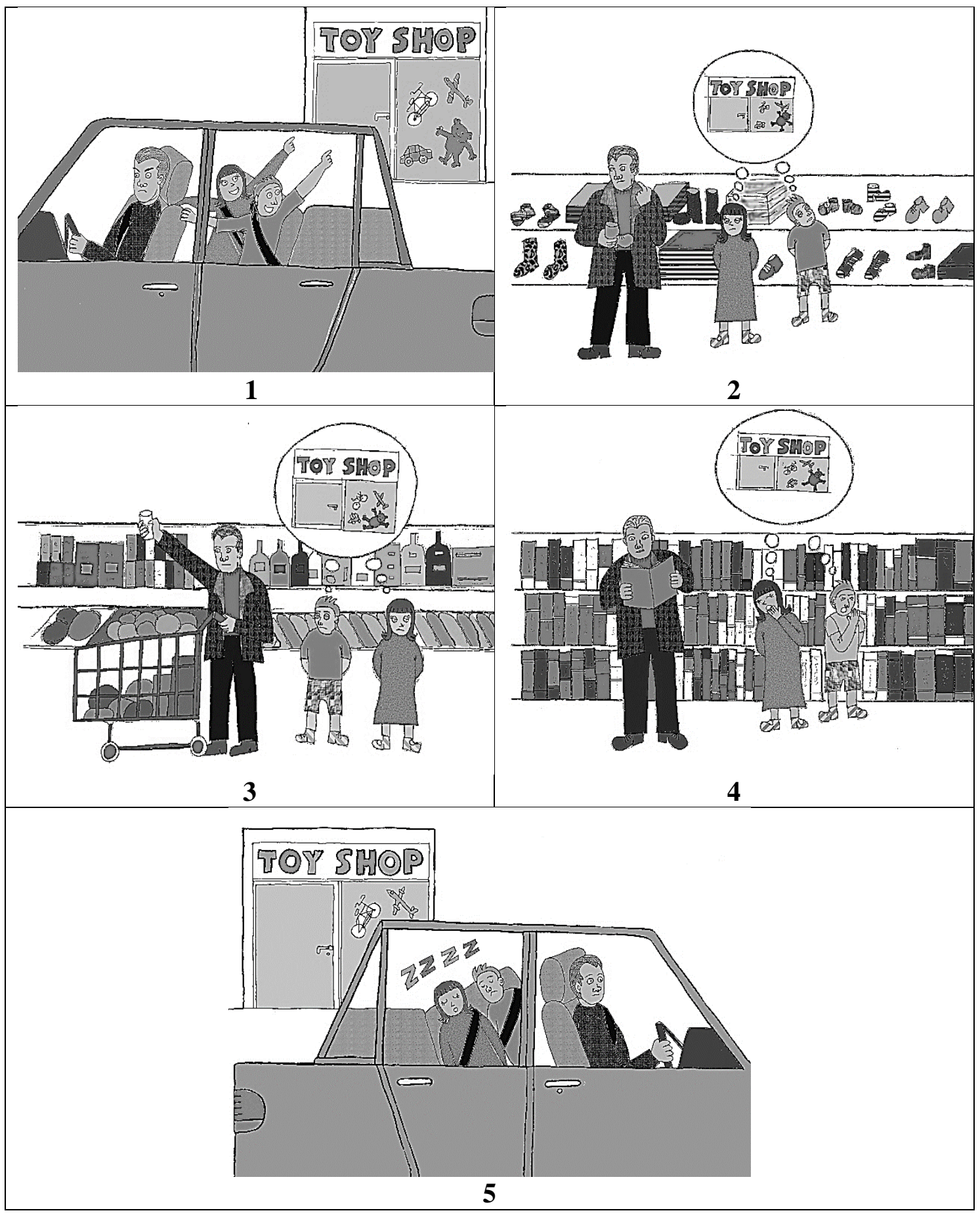


Story builder's sheet, showing pictures in random order plus 3 distractors

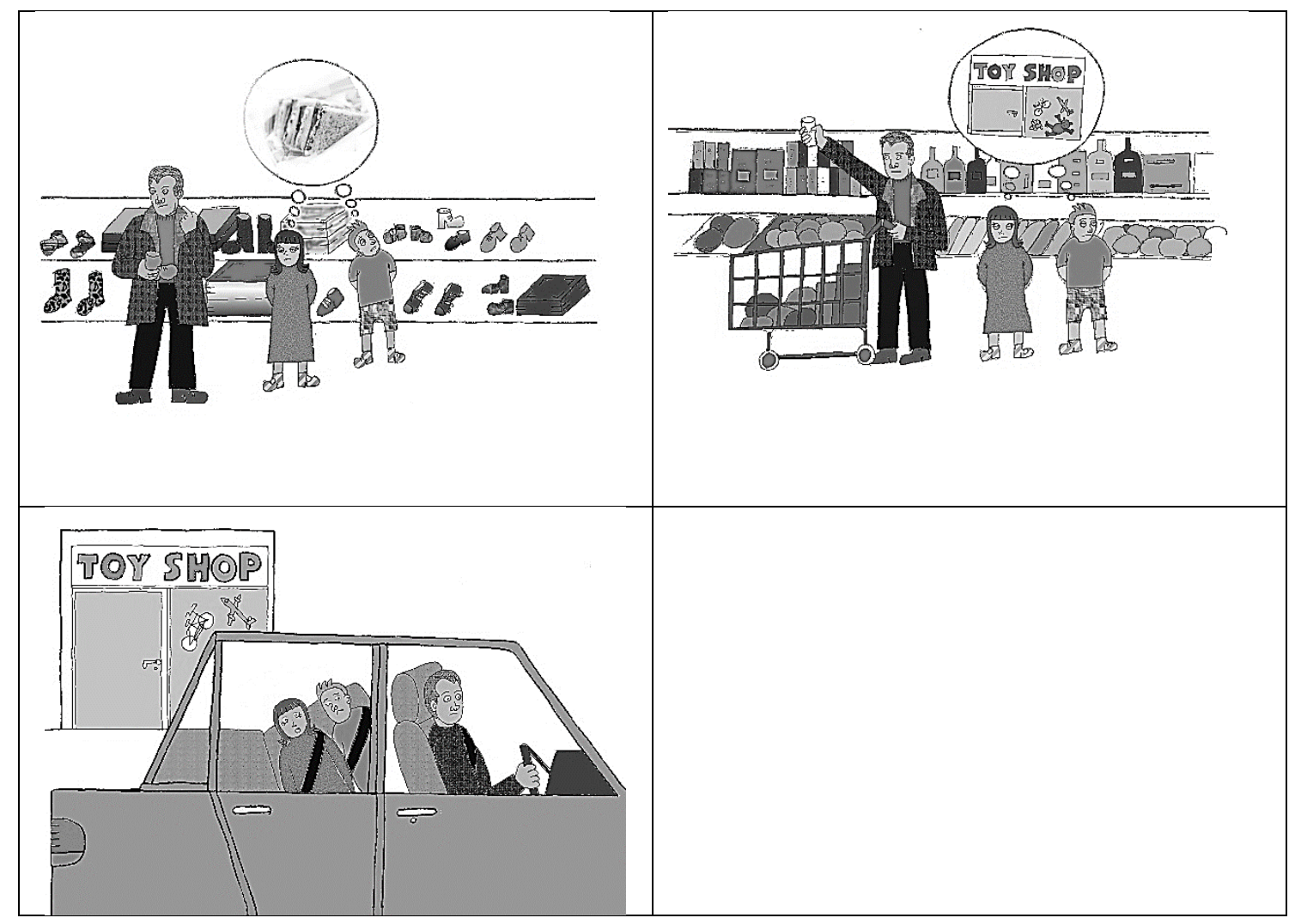




\section{APPENDIX B - RAW DATA}

L1 Use: total (narrators and story builders over total number of utterances)

\begin{tabular}{|l|l|c|c|}
\hline \multicolumn{2}{|c|}{ Children -A1 (20 subjects) } & L1 use & Percentage \\
\hline D1T1 & Utterances & 297 & \\
\hline D1T1 & L1 use & 0 & $0 \%$ \\
\hline D1T2 & Utterances & 494 & \\
\hline D1T2 & L1 use & 6 & $1.21 \%$ \\
\hline D1 & Utterances & 791 & \\
\hline D1 & L1 use & 6 & $0.76 \%$ \\
\hline D2T1 & Utterances & 320 & \\
\hline D2T1 & L1 use & 3 & $0.94 \%$ \\
\hline D2T2 & Utterances & 465 & \\
\hline D2T2 & L1 use & 9 & $1.94 \%$ \\
\hline D2 & Utterances & 785 & \\
\hline D2 & L1 use & 12 & $1.53 \%$ \\
\hline
\end{tabular}

L1 Structural transfer: total (narrators and story builders over total number of utterances)

\begin{tabular}{|l|c|c|}
\hline \multicolumn{1}{|c|}{ Children -A1 } & Structural transfer & Percentage \\
\hline D1T1 Story builders & 27 & $9.09 \%$ \\
\hline D1T2 Narrators & 47 & $9.51 \%$ \\
\hline & \multicolumn{2}{|c|}{} \\
\hline Total D1 & 74 & $9.36 \%$ \\
\hline & 58 & $18.13 \%$ \\
\hline D2T1 & 46 & $14.38 \%$ \\
\hline D2T1 Narrators & 12 & $3.75 \%$ \\
\hline D2T1 Story builders & 56 & $12.04 \%$ \\
\hline & 37 & $7.96 \%$ \\
\hline D2T2 & 19 & $4.09 \%$ \\
\hline D2T2 Narrators & 114 & $14.52 \%$ \\
\hline D2T2 Story builders & 130 & $8.24 \%$ \\
\hline \multicolumn{2}{|c|}{} \\
\hline Total D2 & 58 & $3.68 \%$ \\
\hline Total Narrators (D1+D2) & \multicolumn{2}{|c|}{} \\
\hline Total Story builders (D1+D2) &
\end{tabular}




\section{BIBLIOGRAPHY}

Agustín-Llach, M. P. (2009). The role of Spanish L1 in the vocabulary use of CLIL and non-CLIL EFL learners. Content and language integrated learning: Evidence from research in Europe, $41,112$.

Alegría de la Colina, A., \& García Mayo, M. P. (2009). Oral interaction in task-based EFL learning: The use of the L1 as a cognitive tool. IRAL-International Review of Applied Linguistics in Language Teaching, 47(3-4), 325-345.

Allwright, R. L. (1996). Making sense of life in the language classroom: the significance of participant orientations. Unpublished manuscript. Lancaster, UK: Lancaster University.

Antón, M., \& DiCamilla, F. J. (1998). Socio-cognitive functions of L1 collaborative interaction in the L2 classroom. Canadian Modern Language Review, 54(3), 314-342.

Azkarai, A., \& García Mayo, M. P. (2017). Task repetition effects on L1 use in EFL child task-based interaction. Language teaching research, 21(4), 480-495.

Azkarai, A., \& Imaz Agirre, A. (2015). Negotiation of Meaning Strategies in Child EFL Mainstream and CLIL Settings. Tesol Quarterly.

Bell, A. (1984). Language style as audience design. Language in society, 13(2), 145-204.

Berry, V. (1997). Gender and personality as factors of interlocutor variability in oral performance tests. Paper presented at the 19th Language Testing Research Colloquium, Orlando, Florida.

Broner, M. A. (2001). Impact of interlocutor and task on first and second language use in a Spanish immersion program (Vol. 18): Center for Advanced Research on Language Acquisition, University of Minnesota.

Buckingham, A. (1997). Oral language testing: Do the age, status and gender of the interlocutor make a difference. Unpublished MA dissertation, University of Reading.

Celaya, M. L. (1992). Present continuous or simple present?: Mother tongue influence in EFL. Atlantis, 29-36.

Celaya, M. L., \& Torras, M. R. (2001). L1 influence and EFL vocabulary. Do children rely more on $L 1$ than adult learners. Paper presented at the Proceedings of the 25th AEDEAN Conference.

Cook, V. (2001). Using the first language in the classroom. Canadian Modern Language Review, $57(3), 402-423$.

Chambers, L., Galaczi, E. D., \& Gilbert, S. (2012). Test-taker familiarity in speaking tests: Does it make a difference? Cambridge ESOL Research Notes forthcoming(49), 33-40.

DiCamilla, F. J., \& Antón, M. (2012). Functions of L1 in the collaborative interaction of beginning and advanced second language learners. International Journal of Applied Linguistics, 22(2), 160-188.

Duff, P. A., Rossiter, M. J., Derwing, T. M., \& Jones, V. M. (2008). Is a picture worth a thousand words? Tesol Quarterly, 42(2), 325-329.

Dulay, H., \& Burt, M. (1974). Errors and strategies in child second language acquisition. Tesol Quarterly, 129-136.

Ecke, P. (2001). Lexical retrieval in a third language: Evidence from errors and tip-of-the-tongue states. Bilingual Education and Bilingualism, 90-114.

Gabrys-Barker, D. (2006). The interaction of languages in the lexical search of multilingual language users. Cross-linguistic Influences in the Second Language Lexicon. Clevedon: Multilingual Matters.

García Mayo, M. P., \& Hidalgo, M. A. (2017). L1 use among young EFL mainstream and CLIL learners in task-supported interaction. System.

García Mayo, M. P., \& Imaz Agirre, A. (2017). Child EFL interaction; age, instructional setting and development. Multilingual Matters(Early language learning Complexity and mixed methods), 249-268. 
García Mayo, M. P., \& Lázaro-Ibarrola, A. (2015a). Do children negotiate for meaning in taskbased interaction? Evidence from CLIL and EFL settings. System. doi: 10.1016/j.system.2014.12.001

García Mayo, M. P., \& Lázaro-Ibarrola, A. (2015b). Do children negotiate for meaning in taskbased interaction? Evidence from CLIL and EFL settings. System, 54, 40-54.

Gass, S. M., \& Varonis, E. M. (1985a). Task variation and nonnative/nonnative negotiation of meaning. In: Gass, S.M., Madden, C.G. (Eds.), Input in second language acquisition. Rowley, MA: Newbury House, 149-161.

Geva, E. (2006). Second-language oral proficiency and second-language literacy. Developing literacy in second-language learners: Report of the National Literacy Panel on LanguageMinority Children and Youth, 123-139.

Gost, C., \& Celaya, M. L. (2005). Age and the use of L1 in EFL oral production. Perspectivas interdisciplinares de la lingüística aplicada, 129-136.

Hammarberg, B. (2001). Roles of 1 and L2 in L3 production and acquisition. Cross-linguistic influence in third language acquisition: Psycholinguistic perspectives, 31, 21.

Herwig, A. (2001). Plurilingual lexical organisation: Evidence from lexical processing in L1-L2-L3L4 translation. Bilingual Education and Bilingualism, 115-137.

James, C. (2013). Errors in language learning and use: Exploring error analysis: Routledge.

Jarvis, S., \& Pavlenko, A. (2008). Crosslinguistic influence in language and cognition: Routledge.

Lázaro-Ibarrola, A., \& Azpilicueta-Martínez, R. (2015). Investigating negotiation of meaning in EFL children with very low levels of proficiency. International Journal of English Studies, 15((1)), 1-21.

Lázaro-lbarrola, A., \& Hidalgo, M. A. (2017). Benefits and limitations of conversational interactions among young learners of English in a CLIL context. Learning Foreign Languages in Primary School: Research Insights(Multilingual Matters), 86-102.

Lázaro, A., \& Garcia Mayo, M. P. (2012). L1 use and morphosyntactic development in the oral production of EFL learners in a CLIL context. International Review of Applied Linguistics in Language Teaching, 50(2), 135-160.

Lightbown, P., \& Spada, N. M. (2006). How languages are learned: Oxford University Press, USA.

Long, M. H. (1996). The role of the linguistic environment in second language acquisition. In: Ritchie, W.C., Bhatia, T.K. (Eds.), Handbook of Research on Language Acquisition. Academic Press, New York, 413-468.

Lyster, R. (2001). Negotiation of form, recasts, and explicit correction in relation to error types and learner repair in immersion classrooms. Language Learning, 51(s1), 265-301.

Lyster, R., \& Izquierdo, J. (2009). Prompts versus recasts in dyadic interaction. Language Learning, 59(2), 453-498.

Macaro, E. (2005). Codeswitching in the L2 classroom: A communication and learning strategy. Non-native language teachers, 63-84.

Mackey, A., \& Oliver, R. (2002). Interactional feedback and children's L2 development. System, 30(4), 459-477.

Mackey, A., Oliver, R., \& Leeman, J. (2003). Interactional input and the incorporation of feedback: An exploration of NS-NNS and NNS-NNS adult and child dyads. Language Learning, 53(1), 35-66.

Möhle, D. (1989). Multilingual interaction in foreign language production. Interlingual processes, 179-194.

Navés, T., Miralpeix, I., \& Celaya, M. L. (2005). Who transfers more... and what? Crosslinguistic influence in relation to school grade and language dominance in EFL. International Journal of Multilingualism, 2(2), 113-134.

Neokleous, G. (2017). Closing the Gap: Student Attitudes Toward First Language Use in Monolingual EFL Classrooms. TESOL Journal, 8(2), 314-341. 
Odlin, T., \& Jarvis, S. (2004). Same source, different outcomes: A study of Swedish influence on the acquisition of English in Finland. International Journal of Multilingualism, 1(2), 123140.

Oliver, R. (1995a). Negative feedback in child NS/NNS conversation. Studies in Second Language Acquisition, 18, 459-481.

Oliver, R. (1995b). Negotiation and feedback in child second language acquisition. Unpublished doctoral thesis, The University of Western Australia, Perth.

Oliver, R. (1998). Negotiation of meaning in child interactions. The relationship between conversational interaction and second language acquisition. Modern Language Journal, $82,372-386$.

Oliver, R. (2000). Age differences in negotiation and feedback in classroom and pairwork. Language Learning, 50(1), 119-151.

Oliver, R. (2002). The Patterns of Negotiation for Meaning in Child Interactions. The Modern Language Journal, 86(1), 97-111. doi: 10.1111/1540-4781.00138

Oliver, R., \& Mackey, A. (2003). Interactional context and feedback in child ESL classrooms. The Modern Language Journal, 87(4), 519-533.

Philp, J., Oliver, R., \& Mackey, A. (2008). Second language acquisition and the younger learner: child's play? (Vol. 23): John Benjamins Publishing.

Philp, J., \& Tognini, R. (2009). Language acquisition in foreign language contexts and the differential benefits of interaction. IRAL-International Review of Applied Linguistics in Language Teaching, 47(3-4), 245-266.

Pica, T., \& Doughty, C. (1985b). The role of group work in classroom second language acquisition. Studies in Second Language Acquisition, 7, 233-248.

Pienemann, M., Johnston, M., \& Brindley, G. (1988). Constructing an acquisition-based procedure for second language assessment. Studies in Second Language Acquisition, 10(02), 217-243.

Pinter, A. (2006). Verbal evidence of task related strategies: Child versus adult interactions. System, 34(4), 615-630.

Pladevall-Ballester, E., \& Vraciu, A. (2017). Exploring early EFL: L1 use in oral narratives by CLIL and non-CLIL primary school learners. . In M. P. García Mayo (Ed.), Learning foreign languages in primary school: Research insights. (in press).(Multilingual Matters ).

Porter, D. (1991). Affective Factors in the Assessment of Oral Interaction: Gender and Status.

Porter, D., \& Shen, S. H. (1991). Sex, status and style in the Interview. The Dolphin, 21, 117-128.

Porter, P. A. (1986). How learners talk to each other: Input and interaction in task-centred discussions.In: Day, R.R. (Ed.),Talking to learn: Conversation and second language acquisition. Rowley, MA: Newbury House, 35-56.

Poulisse, N. (Ed.). (1990). The Use of Compensatory Strategies by Dutch Learners of English: Dordrecht: Foris.

Poulisse, N., \& Bongaerts, T. (1994). First language use in second language production. Applied Linguistics, 15(1), 36-57.

Ringbom, H. (2001). Lexical transfer in L3 production. Bilingual Education and Bilingualism, 5968.

Sánchez, L. (2003). Cross-linguistic influence and age. Paper presented at the Third International Conference on Third Language Acquisition and Trilingualism. Tralee, Eire-Ireland. .

Sanchez, L., \& Jarvis, S. (2008). The use of picture stories in the investigation of crosslinguistic influence. Tesol Quarterly, 42(2), 329-333.

Sanz, C. (2000). Bilingual education enhances third language acquisition: Evidence from Catalonia. Applied Psycholinguistics, 21(1), 23-44.

Schumann, J. (1979). The acquisition of English negation by speakers of Spanish: A review of the literature. The acquisition and use of Spanish and English as first and second languages, 3-32. 
Serra, C. (2007). Assessing CLIL at primary school: A longitudinal study. International Journal of Bilingual Education and Bilingualism, 10(5), 582-602.

Storch, N., \& Aldosari, A. (2010). Learners' use of first language (Arabic) in pair work in an EFL class. Language teaching research, 14(4), 355-375.

Tognini, R. (2008). Interaction in languages other than English classes in Western Australian primary and secondary schools: theory, practice and percentions.

Tognini, R., \& Oliver, R. (2012). L1 use in primary and secondary foreign language classrooms and its contribution to learning. Language learners' discourse in instructional settings, 53-78.

Turnbull, M., \& Arnett, K. (2002). Teachers' uses of the target and first languages in second and foreign language classrooms. Annual review of applied linguistics, 22, 204-218.

Wells, G. (1999). Using L1 to Master L2: A Response to Antón and DiCamilla's 'Socio-Cognitive Functions of L1 Collaborative Interaction in the L2 Classroom'. The Modern Language Journal, 83(2), 248-254.

White, J. (1998). Getting the learners' attention. Focus on Form in Classroom Second Language Acquisition, 85.

Wode, H. (1978). Developmental sequences in naturalistic SLA. HATCH, E. Readings in second language acquisition. Rowley, MA: Newbury House.

Yule, G., \& Macdonald, D. (1990). Resolving referential conflicts in L2 interaction: The effect of proficiency and interactive role. Language Learning, 40, 539-556. 